\title{
Implementing the American Woodcock Conservation Plan: Wildlife Management Institute's Young Forest Initiative
}

\author{
STEVE WEBER, Consultant to Wildlife Management Institute, 1085 Lake Road, Panton, Vermont, USA 05491 \\ THOMAS R. COOPER, U.S. Fish and Wildlife Service, Region 3 Migratory Bird Program, 5600 American Blvd West, \\ Bloomington, Minnesota, USA 55425
}

Proceedings of the American Woodcock Symposium 11: 5-8

The Woodcock Task Force, under the direction of the Association of Fish and Wildlife Agencies, completed the American Woodcock Conservation Plan (Plan) in 2008. The goal of the Plan was to halt the decline of American woodcock (Scolopax minor, hereafter woodcock) populations and to return populations to densities that provide adequate opportunity for utilization of the woodcock resource (Kelley et al., 2008). Specific objectives of the Plan were: 1) halt woodcock population declines by 2012 as measured by the American Woodcock Singing-ground Survey (SGS), 2) achieve positive population growth by 2022 as measured by the SGS, 3 ) halt decline of early successional forest by 2012 as measured by the Forest Inventory Analysis system (FIA), and 4) increase early successional forest by 2022 as measured by the FIA (Kelley et al. 2008).

Upon completion of the Plan, the Wildlife Management Institute (WMI) took a leadership role in implementing the Plan by forming 5 regional "Young Forest Initiatives" (Initiatives) covering 17 states within the core breeding range of woodcock (Fig. 1). The Upper Great Lakes Initiative includes all Michigan and Wisconsin, and over half of Minnesota in the northeast quadrant of the state. The Lower Great Lakes Initiative includes lands south of lakes Erie and Ontario in Ohio and Pennsylvania, and land in the St. Lawrence Valley in New York, the Champlain Valley in New York and Vermont, and the Hudson River Valley in New York. The Northern Forest Initiative includes all of Maine, most of New Hampshire, northern and western Massachusetts, and the Adirondack region of New York. The Appalachian Initiative includes all of West Virginia, southeastern Ohio, much of Pennsylvania, the southern tier of New York, the northern tip of New Jersey, and western Virginia. The Atlantic Coast Initiative includes coastal portions of Maine and New Hampshire, all of Rhode
Island, Long Island, and extreme southeastern New York, southern New Jersey, the Delmarva Peninsula, and that portion of Maryland on the western shore of the Chesapeake Bay.

WMI brought together regional partners, starting in 2007, to begin implementing the habitat management objectives of the plan. Guiding principles for the initiatives were: 1) all work is science-based, 2) expert practitioners deliver conservation, 3) initiatives are partnership driven, and 4) there is accountability within the partnership.

\section{PLAN IMPLEMENTATION}

In the early phases of each Initiative, WMI coordinated organizational meetings with potential regional partners. At these meetings, attendees learned more about the goals of the American Woodcock Conservation Plan and identified opportunities for coordinating work throughout the Initiative. Partners also identified available tools (e.g., spatially explicit woodcock abundance models developed by Thogmartin et al., 2007) for focusing work, as well as any existing information gaps.

WMI contracted with $>30$ habitat management specialists across the 5 Young Forest Initiatives to work on meeting plan goals. By taking advantage of a wave of retirements by state and federal natural resource agency staff, WMI assembled a team of highly trained and networked contractors to work with public and private partners to create and maintain early successional forest to benefit woodcock and $>60$ other species of greatest conservation need across the landscape. WMI employees and contractors coordinated with public and private partners to increase awareness of young forest/woodcock habitat issues and to implement habitat management projects. In some portions of the woodcock range, contractor work has also included management aimed at other species that 
require young forest cover types, including golden-winged warblers (Vermivora chrysoptera), New England cottontail (Sylvilagus transitionalis), ruffed grouse (Bonasa umbellus), and massasauga rattlesnakes (Sistrurus catenatus). Habitat management for these species results in young forest cover that also benefits woodcock. WMI funded the contractors through a series of grants from the National Fish and Wildlife Foundation, the U.S. Fish and Wildlife Service, state conservation agencies, the U.S. Department of Agriculture Natural Resource Conservation Service, and other partners (e.g., other non-profit organizations and private foundations).

To assist with initiative communication efforts, WMI worked with D.J. Case and Assoc. to develop a Communications Strategy (Seng and Case 2019), which has guided outreach efforts and currently supports 3 websites (www. timberdoodle.org, www.youngforest.org, and www.newenglandcottontail.org). These websites contain an abundance of information on techniques and tools, as well as success stories. WMI, with the assistance of partners, has developed a wide range of technical assistance publications, including regional Best Management Practices for woodcock, several landowner guides, communication handbooks, brochures, large format ( $8^{1 / 2} \times 11$ inches) science and stewardship guides, displays, guidebooks and manuals, exhibits, fact sheets, signs, and PowerPoint presentations. Many of these products are available at www. timberdoodle.org.

\section{INITIATIVE ACCOMPLISHMENTS}

WMI maintains an online database that allows contractors to enter accomplishments from their work and that of partners. Since January, 2008, WMI has documented

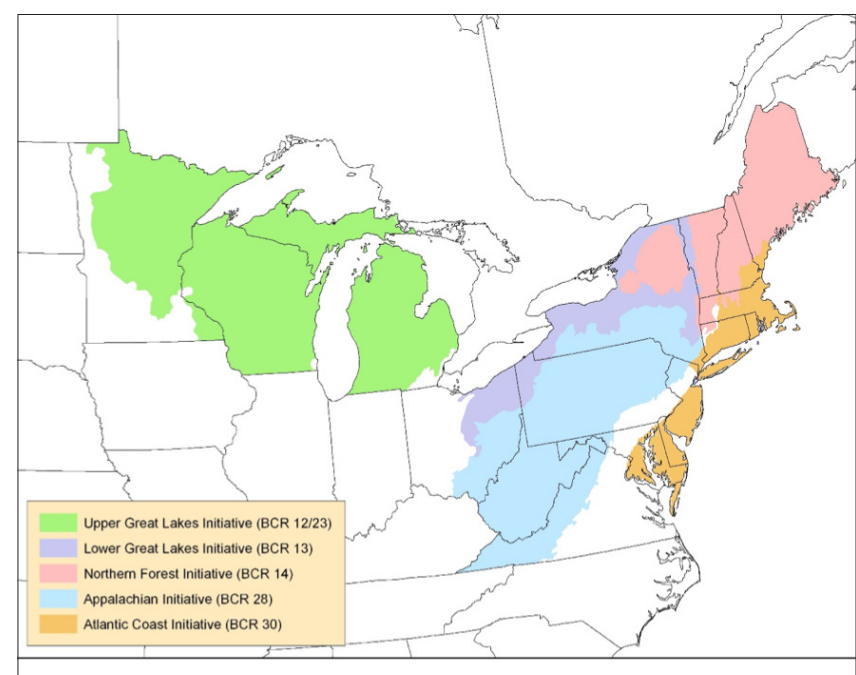

Figure 1. Location of the 5 Bird-Conservation-

Region (BCR)-based Young Forest Initiatives in the United States.
1,429 assessments on 358,670 hectares (886,293 acres) of land across the initiatives (Table 1) and 2,692 treatments by public and private partners on 70,856 hectares (176,111 acres; Table 2). Initiative partners have been directly involved in 923 outreach events of all types, interacting with $\geq 12,272$ interested landowners (Table 3). Not all accomplishments end up being entered into the database, and the number of people attending outreach events was not incorporated into the reporting until December, 2015. As such, all accomplishments should be considered as minimum numbers. Summaries for assessments, treatments, and outreach efforts for each of the initiatives are presented in Tables 1-3.

\section{CONCLUSIONS}

Partners have made progress in increasing the awareness of the value of young forest for woodcock and some 65 species of greatest conservation need that are closely associated with young forest. Whereas woodcock numbers have stopped their decades-long decline as measured by the SGS, there has not been an indication of population increase towards established goals, and the amount of young forest (age $0-20$ years) continues to decline in most states. Efforts through these initiatives, in cooperation with partners, have likely helped stabilize woodcock populations, and in some areas initiated slight increases. Continued progress in these initiatives can help benefit wildlife species requiring young forest cover, and we recommend future work focus on engaging new partners in the existing initiatives and expanding initiative work into Canada.

\section{LITERATURE CITED}

Seng, P.T. and D.J. Case. 2019. Communicating effectively about young forest management to benefit early successional species. Pages $67-75$ in D.G. Krementz, D.E. Andersen, and T. R. Cooper, Editors. Proceedings of the Eleventh American Woodcock Symposium. University of Minnesota Libraries Publishing, Minneapolis, Minnesota, USA.

Kelley, J. R., S.J. Williamson, and T. R. Cooper, editors. 2008. American Woodcock Conservation Plan: a summary of and recommendations for woodcock conservation in North America, Migratory Shore and Upland Game Bird Working Group, Association of Fish and Wildlife Agencies. Wildlife Management Institute, Washington, D.C., USA <https://www.fws.gov/migratorybirds/pdf/surveys-and-data/Webless\%2oMigratory\%20 Game\%2oBirds/American\%2oWoodcock\%2opdf\%2ofiles/ WoodcockConservationPlan.pdf $>$. Accessed 10 June 2019. 
Table 1. Summary of the number of assessments completed and hectares (acres) assessed for the 5 Young Forest Initiatives by primary species.

\begin{tabular}{lrr}
\hline Primary Species & $\begin{array}{r}\text { No. of } \\
\text { Assess- } \\
\text { ments }\end{array}$ & $\begin{array}{r}\text { Hectares } \\
\text { assessed (acres) }\end{array}$ \\
\hline UPPER GREAT LAKES INITIATIVE & \\
American Woodcock & 7 & $3,609(8,917)$ \\
Golden-winged Warbler & 1 & $691(1,707)$ \\
Ruffed Grouse & 2 & $2,060(5,090)$ \\
$\quad$ Total & 10 & $6,360(15,714)$ \\
\hline LOWER GREAT LAKES INITIATIVE & \\
American Woodcock & 148 & $17,480(43,194)$ \\
Golden-winged Warbler & 127 & $7,287(18,007)$ \\
Massasauga Rattlesnake & 1 & $11(27)$ \\
New England Cottontail & 22 & $2,498(6,173)$ \\
$\quad$ Total & 298 & $27,276(67,401)$ \\
\hline NORTHERN FOREST INITIATIVE & \\
American Woodcock & 323 & $169,793(419,568)$ \\
Golden-winged Warbler & 3 & $212(525)$ \\
New England Cottontail & 83 & $4,130(10,205)$ \\
Ruffed Grouse & 15 & $2,073(5,122)$ \\
$\quad$ Total & 424 & $176,208(435,420)$ \\
\hline APPALACHIAN INITIATIVE & & \\
American Woodcock & 224 & $108,111(267,148)$ \\
Golden-winged Warbler & 60 & $11,716(28,951)$ \\
Massasauga Rattlesnake & 1 & $162(400)$ \\
New England Cottontail & 44 & $3,644(9,004)$ \\
Ruffed Grouse & 24 & $10,943(27,041)$ \\
$\quad$ Total & 353 & $134,576(332,544)$ \\
\hline ATLANTIC COAST INITIATIVE & & \\
American Woodcock & 67 & $4,067(10,049)$ \\
New England Cottontail & 276 & $10,102(24,962)$ \\
Ruffed Grouse & 1 & $81(200)$ \\
$\quad$ Total & 344 & $14,250(35,211)$ \\
\hline OVERALL SUMMARY & & 1,429 \\
American Woodcock & 769 & $303,060(748,877)$ \\
Golden-winged Warbler & 191 & $19,906(49,190)$ \\
Massasauga Rattlesnake & 2 & $173(427)$ \\
New England Cottontail & 425 & $20,374(50,345)$ \\
Ruffed Grouse & & $(37,453)$ \\
\hline & & \\
\hline
\end{tabular}

Table 2. Summary of the number of treatments and hectares (acres) of vegetation managed for the 5 Young Forest Initiatives by primary species.

\begin{tabular}{lrr}
\hline Primary Species & $\begin{array}{r}\text { No. of } \\
\text { Assess- } \\
\text { ments }\end{array}$ & $\begin{array}{r}\text { Hectares } \\
\text { assessed (acres) }\end{array}$ \\
\hline UPPER GREAT LAKES INITIATIVE & \\
American Woodcock & 128 & $29,673(73,326)$ \\
Golden-winged Warbler & 4 & $55(136)$ \\
$\quad$ Total & 132 & $29,729(73,462)$ \\
\hline LOWER GREAT LAKES INITIATIVE & \\
American Woodcock & 147 & $864(2,137)$ \\
Golden-winged Warbler & 16 & $125(310)$ \\
Massasauga Rattlesnake & 4 & $25(61)$ \\
New England Cottontail & 13 & $32(79)$ \\
Ruffed Grouse & 2 & $2(4)$ \\
$\quad$ Total & 182 & $1,048(2,590)$ \\
\hline NORTHERN FOREST INITIATIVE & \\
American Woodcock & 1,452 & $23,245(57,439)$ \\
New England Cottontail & 39 & $404(998)$ \\
Ruffed Grouse & 12 & $34(83)$ \\
$\quad$ Total & 1,503 & $23,682(58,519)$ \\
\hline APPALACHIAN INITIATIVE & & \\
American Woodcock & 311 & $7,812(19,303)$ \\
Golden-winged Warbler & 102 & $4,556(11,258)$ \\
New England Cottontail & 26 & $172(424)$ \\
Ruffed Grouse & 25 & $969(2,394)$ \\
$\quad$ Total & 464 & $13,508(33,379)$ \\
\hline ATLANTIC COAST INITIATIVE & & $666(1,646)$ \\
American Woodcock & 87 & $6(15)$ \\
New England Cottontail & 323 & $2,216(5,477)$ \\
Ruffed Grouse & 1 & $2,889(7,138)$ \\
$\quad$ Total & 411 & 2,692 \\
\hline OVERALL SUMMARY & & $70,856(175,088)$ \\
\hline American Woodcock & 2,125 & $62,260(153,848)$ \\
Golden-winged Warbler & 122 & $4,736(11,703)$ \\
Massasauga Rattlesnake & 4 & $25(61)$ \\
New England Cottontail & 401 & $2,824(6,978)$ \\
Ruffed Grouse & & \\
\hline
\end{tabular}


Table 3. Summary of outreach activities for the 5 Young Forest Initiatives by primary activity type.

\begin{tabular}{|c|c|c|c|c|c|}
\hline Outreach type & $\begin{array}{l}\text { No. of } \\
\text { events }\end{array}$ & $\begin{array}{r}\text { No. } \\
\text { attending }\end{array}$ & Outreach type & $\begin{array}{l}\text { No. of } \\
\text { events }\end{array}$ & $\begin{array}{r}\text { No. } \\
\text { attending }\end{array}$ \\
\hline \multicolumn{3}{|c|}{ UPPER GREAT LAKES INITIATIVE } & \multicolumn{3}{|c|}{ ATLANTIC COAST INITIATIVE } \\
\hline Article & 6 & NA & Article & 12 & NA \\
\hline Consultation & 132 & NA & Consultation & 51 & NA \\
\hline Field Workshop & 9 & 228 & Exhibit & 31 & 1,372 \\
\hline Indoor presentation & 27 & NA & Field Workshop & 33 & 589 \\
\hline Total & 174 & 228 & Indoor/Outdoor event & 8 & 153 \\
\hline \multicolumn{3}{|c|}{ LOWER GREAT LAKES INITIATIVE } & Indoor presentation & 78 & 830 \\
\hline Article & 6 & NA & Mailing & 33 & 3,624 \\
\hline Consultation & 17 & NA & Radio Interview & 2 & NA \\
\hline Exhibit & 9 & 148 & TV Interview & 3 & NA \\
\hline Field Workshop & 8 & 311 & Total & 251 & 6,568 \\
\hline Indoor/Outdoor event & 12 & 230 & \multicolumn{3}{|l|}{ OVERALL SUMMARY } \\
\hline Indoor presentation & 51 & 627 & Article & 40 & NA \\
\hline Mailing & 6 & 464 & Consultation & 335 & NA \\
\hline Total & 109 & 1,780 & Exhibit & 58 & 2,700 \\
\hline \multicolumn{3}{|c|}{ NORTHERN FOREST INITIATIVE } & Field Workshop & 107 & 2,261 \\
\hline Article & 1 & NA & Indoor/Outdoor event & 29 & 628 \\
\hline Consultation & 51 & NA & Indoor presentation & 304 & 2,596 \\
\hline Exhibit & 2 & NA & Mailing & 45 & 4,088 \\
\hline Field Workshop & 27 & 455 & Radio Interview & 2 & NA \\
\hline Indoor/Outdoor event & 5 & 163 & TV Interview & 3 & NA \\
\hline Indoor presentation & 53 & 162 & Total & 923 & 12,272 \\
\hline Total & 139 & 780 & \multirow{10}{*}{\multicolumn{3}{|c|}{$\begin{array}{l}\text { a The number of people attending was not recorded for all } \\
\text { outreach activities. Recorded as NA if not known. }\end{array}$}} \\
\hline \multicolumn{3}{|c|}{ APPALACHIAN INITIATIVE } & & & \\
\hline Article & 15 & NA & & & \\
\hline Consultation & 84 & NA & & & \\
\hline Exhibit & 16 & 1,180 & & & \\
\hline Field Workshop & 30 & 678 & & & \\
\hline Indoor/Outdoor event & 4 & 82 & & & \\
\hline Indoor presentation & 95 & 976 & & & \\
\hline Mailing & 6 & NA & & & \\
\hline Total & 250 & 2,916 & & & \\
\hline
\end{tabular}

